\title{
ANALISIS GEMINAT (PENGGANDAAN) KONSONAN BAHASA BATAK TOBA
}

\author{
Asnita Hasibuan $^{(1)}$, Kristina Manullang ${ }^{(2)}$, Veronika Siagian ${ }^{(3)}$ \\ ${ }^{(1)}$ KetuaPeneliti \\ ${ }^{(2)}$ Anggota 1 \\ ${ }^{(3)}$ Anggota 2 \\ Program Studi Pendidikan Bahasa Indonesia,FakultasKeguruan dan Ilmu Pendidikan, Universitas Katolik Santo \\ Thomas, Jl. Setia Budi No. 479-F Tanjung Sari Medan - Kode Pos No. 20132,email-asnita103hasibuan@gmail.com
}

\section{Abstrak}

Tujuan dari penelitian ini untuk mendeskripsikan proses afiksasi dan morfofonemik yang dapat menghasilkan geminat dan jenis-jenis geminat bahasa Batak Toba. Jenis geminat dibedakan berdasarkan proses afiksasi, morfofonemik dan klitisasi serta berdasarkan kemurnian (kesejatian) geminat, yaitu tipe geminat murni atau sejati dan tidak sejati. Peneltian ini dilakukan di desa Sitorang jae kecamatan Narumonda Kabupaten Toba Samosir. Data dalam penelitian ini dikumpulkan melalui penelitian lapangan. Berdasarkan analisis dapat disimpulkan bahwa geminat dalam Bahasa Toba selalu berada di tengah kata. Geminat yang ditemukan adalah [bb], [cc], [dd], [jj], [kk], [pp], [ss], [tt]. Berdasarkan proses morfofonemik, geminat dalam Bahasa Toba hanya terdapat pada bunyi $[\mathrm{maN}\}$, sedangkan geminat berdasarkan proses afiksasi ditemukan prefiks ma-, mar-, pa-, di-, tar-, ha-, hu-, tu-, um-, sufiks -hon, -an, -i, -on. Berdasarkan proses klitisasi geminat ditemukan pada enklitik. Geminat murni atau sejati bersifat leksikal, geminat tidak sejati dihasilkan melalui proses afiksasi dan klitisasi.

Kata kunci : geminat, konsonan bahasa Batak Toba, proses afiksasi, morfofonemik, dan klitisasi

\begin{abstract}
The purpose of this study is to describe the affixation and morphophonemic processes that can produce resonance and the types of geminat Toba Batak language. This type of geminat is distinguished on the basis of the process of affixation, morphophonemic and clitization and based on purity (authenticity) geminat, that is, the type of pure genuineness or true and not true. This research was carried out in the village of Sitorang jae, Narumonda District, Toba Samosir Regency. The data in this study were collected through field research. Based on the analysis it can be concluded that geminat in Toba Language is always in the middle of the word. The gems found are $[\mathrm{bb}],[\mathrm{cc}],[\mathrm{dd}],[\mathrm{jj}],[\mathrm{kk}],[\mathrm{pp}],[\mathrm{ss}],[\mathrm{tt}]$. Based on the morphophonemic process, resonance in the Toba language is only found in sounds $[\mathrm{maN}\}$, while geminat based on the affixation process is found prefixes ma-, mar-, pa-, di-, tar-, ha-, hu-, tu-, um-, suffix -hon, -an, $i$, -on. Based on the geminate clitization process, it is found in enzymes. Pure or true femininity is lexical, non-genuine excitement is produced through the process of affixation and clitization.
\end{abstract}

Keywords: geminat, Toba Batak language consonants, affixation, morphophonemic, and clitization processes

\section{Pendahuluan}

Bahasa selalu perkembangan dan perubahan. Perkembangan dan perubahan itu terjadi karena adanya perubahan sosial, ekonomi dan budaya. Perkembangan bahasa yang cukup pesat terjadi pada bidang ilmu pengetahuan dan teknologi. Kontak pada bidang politik, ekonomi, ilmu pengetahuan dan lainnya dapat menyebabkan suatu bahasa 
terpengaruh oleh bahasa yang lain. Proses saling mempengaruhi antara bahasa yang satu dengan bahasa yang lain tidak dapat dihindarkan.

Bahasa sebagai bagian integral kebudayaan tidak dapat lepas dari masalah di atas. Saling mempengaruhi antarbahasa pasti terjadi, misalnya kosakata bahasa yang bersangkutan, mengingat kosakata itu memiliki sifat terbuka, seperti bahasa Batak Toba.

Bahasa Batak Toba sebenarnya bervariasi menurut daerah geografisnya, sehingga terdapat dialek-dialek yang didaerah Tapanuli Utara disebut dialek Toba Silindung yang meliputi Kota/Kecamatan Tarutung, Kecamatan Sipoholon, Kecamatan Sipahutar, Kecamatan Garoga, Kecamatan Pangaribuan, Kecamatan Pahae Julu, Kecamatan Adiankoting, Kecamatan Pahae Jae (sebahagian dipengaruhi MandailingAngkola), Kecamatan Pahae Purbatua (sebahagian dipengaruhi MandailingAngkola), dan Kecamatan Simangumban (sebahagian dipengaruhi MandailingAngkola); di daerah Humbang Hasundutan disebut dialek Toba Humbang yang meliputi Kecamatan Siborongborong, Kecamatan Pagaran, Kecamatan Muara, Kabupaten Humbang Hasundutan (kecuali Kecamatan Parlilitan karena pengaruh terirtorial daerah kabupaten Dairi); di daerah Toba Samosir dialek Toba, dan di daerah Samosir yaitu dialek Toba Samosir yaitu hanya Kabupaten Samosir saja, dan dialek Toba Pesisir Pantai Danau Toba yang meliputi keseluruhan Kabupaten Toba Samosir.

Suku Batak Toba yang menggunakan Bahasa Batak Toba, tinggal pada kabupaten Taput, Kabupaten Tobasa, Kabupaten Humbahas, dan Kabupaten Samosir (Limbong \& Silitonga, 2016). Yang penduduknya lebih kurang 14 juta orang. Suku Batak juga mempunyai aksara Batak yang hampir punah, oleh karena yang mampu menulis dan membaca aksara Batak tidak banyak lagi, hanya diketahui segelintir tua-tua Batak dan yang sedang mempelajarinya. Sehingga sekarang penulisan bahasa Batak ditulis dalam huruf Romawi.

Banyak penulisan dan pembacaan pada Bahasa Batak Toba (BBT) tidak sama dalam pembacaannya dengan penulisan, ada asimilasi pada beberapa bunyi. Misalnya :

- $/ \mathrm{k}+\mathrm{h} / \Rightarrow / \mathrm{kk} /$ : ribakhon dibaca /ribakkon/ artinya koyakkan

-. $/ \mathrm{m}+\mathrm{b} /=>/ \mathrm{bb} /$ : somba

/ sobba/ artinya sembah

-. / $\mathrm{m}+\mathrm{h} /$ => /pp/ : paasomhu

paasoppu/ artinya terlalu asam. dll

Pola Kalimat Bahasa Batak Toba sesuai dengan pola kalimat yang dikemukakan Greenberg adalah VOS. Demikian sekelumit tentang Bahasa Batak Toba.

Geminat adalah kaidah sekunder untuk menjelaskan proses penduplikasian konsonan. Kaidah ini tentu saja mengiringi perubahan lain yang terdapat dalam perubahan suatu etimon. Contoh inovasi :

$$
\text { [opung] }=[\text { oppung] ayah/ibunya }
$$

orang tua

[tingkos $]=[$ tikkos $]$ benar

Geminat yaitu rentetan artikulasi yang sama (identik), sehingga menimbulkan ucapan panjang dalam bunyi tersebut, contohnya: Allah dan assalamualaikum.

Dalam Tata Bahasa Batak Toba(Anicetus Sinaga,2014:1) untuk memasuki fonologi bahasa Batak Toba, pertama kita hendak mengenal ucapan setiap kata. Sesudahnya, kita hendak membahas ucapan gabungan kata. Di bawah ini diterapkan masing-masing kata yang sejenis dalam satu kata.

a. Huruf Mati(Konsonan) bahasa Batak Toba

Huruf mati(konsonan), yaitu bunyi bahasa yang dihasilkan dengan menghambat aliran 
udara pada salah satu tempat di saluran suara di atas glottis.

Tabel. Huruf Mati(Konsonan) dan Contoh

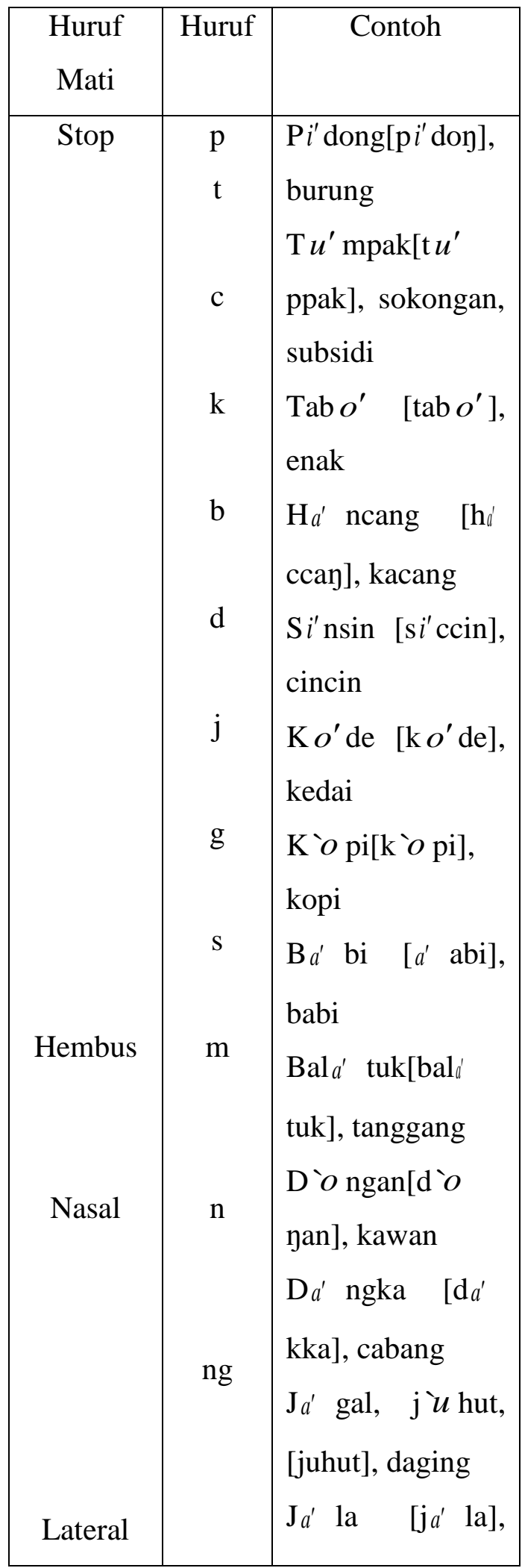

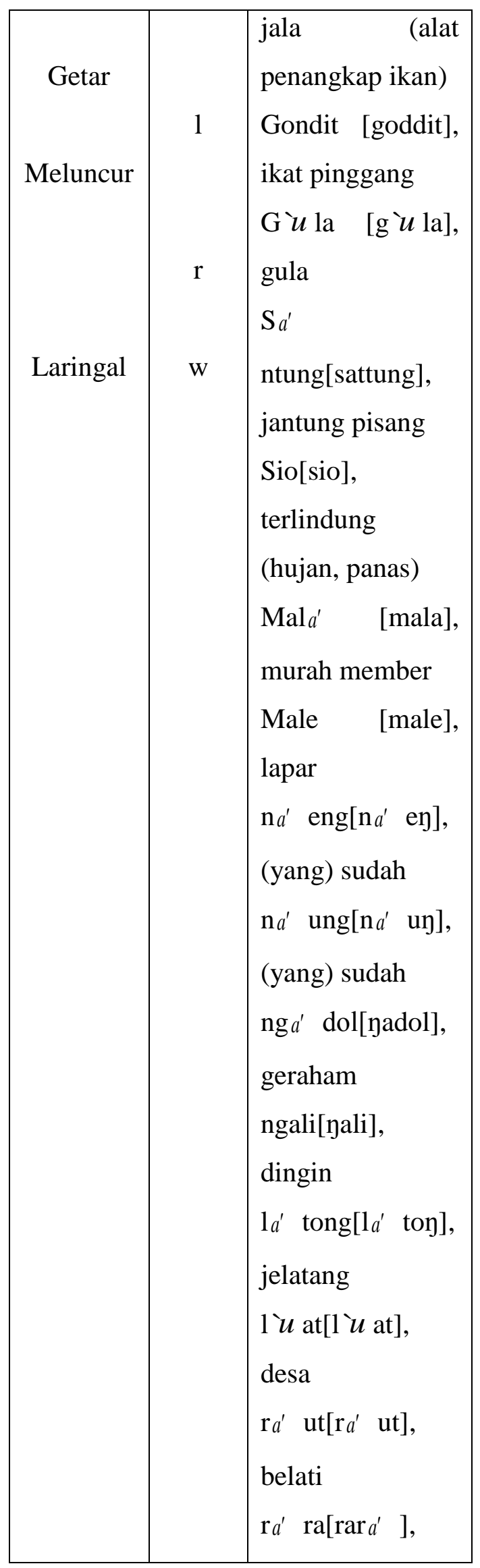




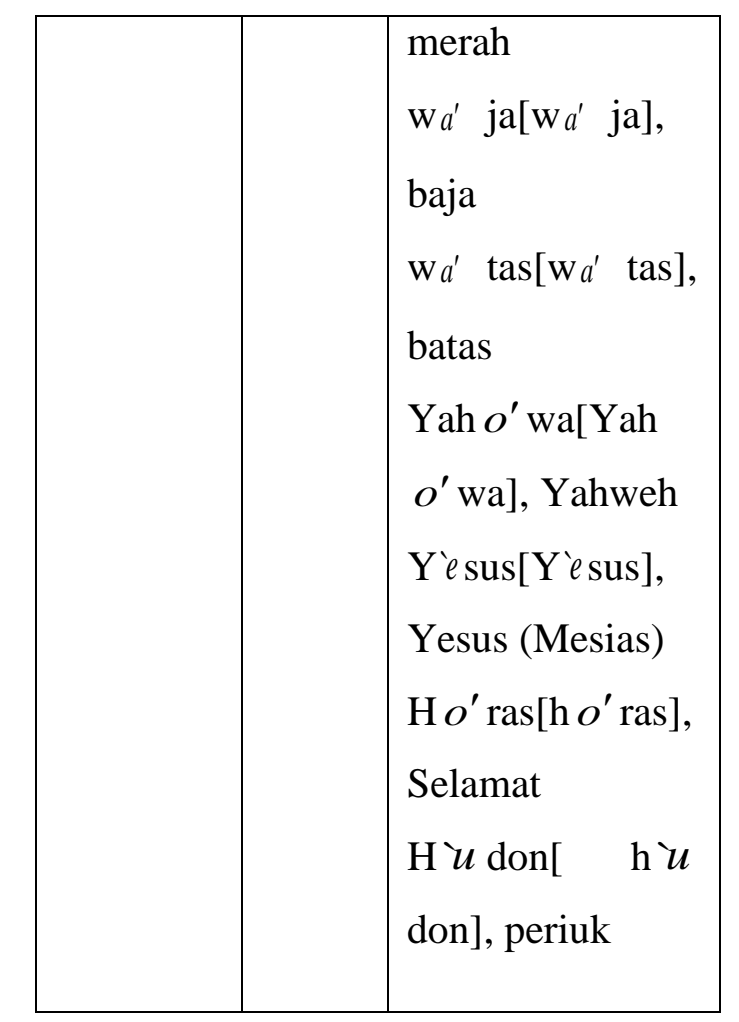

a. Huruf Hidup(Vokal), yaitu bunyi bahasa yang arus udaranya tidak mengalami rintangan.

\begin{tabular}{|c|c|c|}
\hline $\begin{array}{l}\text { Huruf } \\
\text { Hidup }\end{array}$ & Huruf & Contoh \\
\hline $\begin{array}{l}\text { Tinggi } \\
\text { Madya } \\
\text { Rendah }\end{array}$ & $\begin{array}{c}\ddot{ } \\
\\
u^{\prime}\end{array}$ & $\begin{array}{l}\text { t ̈ihas[t } i \\
\text { has], cacat } \\
\text { p inggang[p } \\
\text { inggang], } \\
\text { pinggang } \\
u^{\prime} \text { dan[ } u^{\prime} \\
\text { dan], hujan } \\
\text { m } u^{\prime} \text { la [m } u^{\prime} \\
\text { la], } \\
\text { permulaan } \\
\text { (awal) } \\
\text { metm 'e }\end{array}$ \\
\hline
\end{tabular}

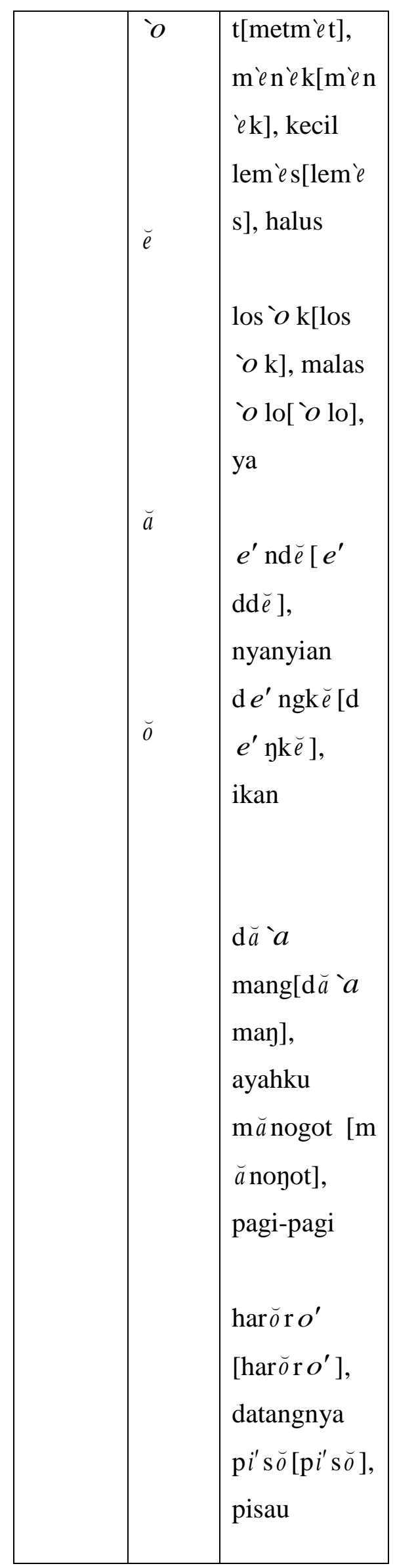




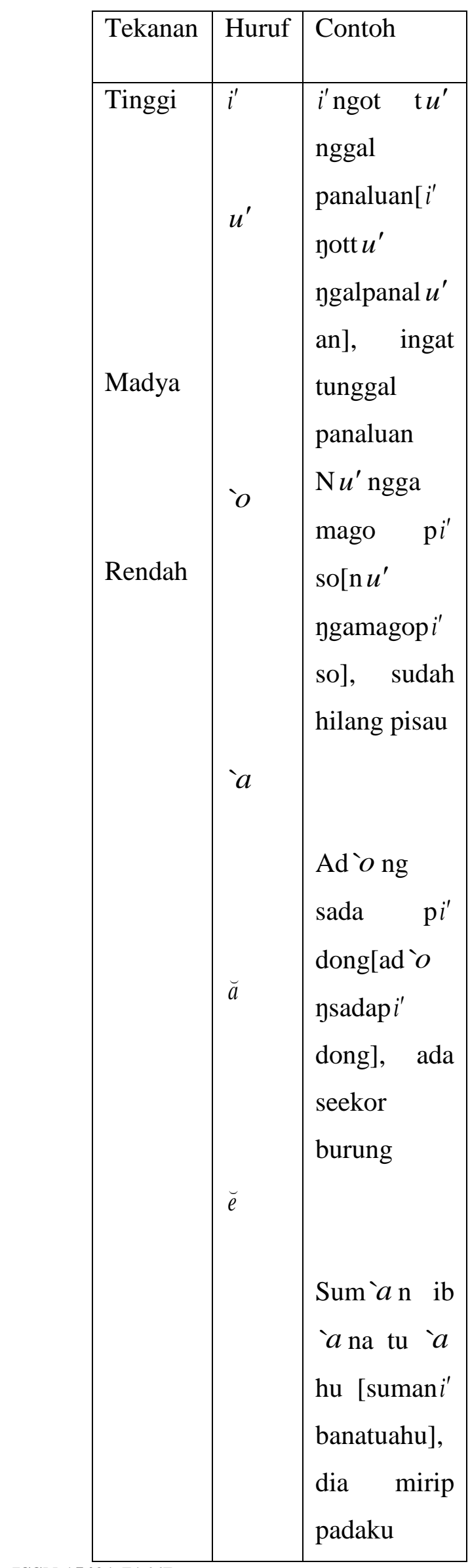

ISSN 15421-71667

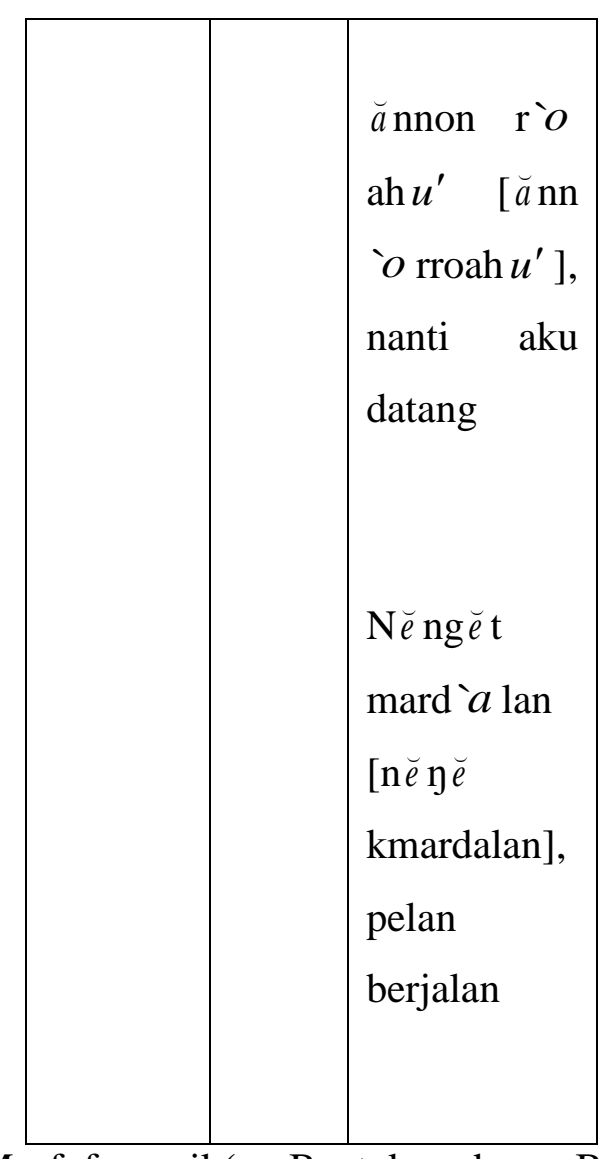

3. Morfofonemik( Bentuk dan Bunyi) Rumang dohot Mangkatahon

Morfofonemik adalah telaah tentang perubahan-perubahan fonem yang terjadi sebagai akibat pertemuan (hubungan) morfem dengan morfem lain.

Hosuk, misang : : musang

Langka : langkah

Tangke : beliung

Tungkot : tongkat

Dongan : kawan, teman

Surat : surat, aksara

Amak : tikar lebar

Halas : lengkuas

Hunik : kunyit

Penelitian ini bertujuan untuk; (1) Mengetahui bentuk geminat konsonan dalam 
bahasa Batak Toba; (2) Mengetahui proses pembentukan geminat konsonan dalam bahasa Batak Toba; (3) Mengetahui penggunaan geminat konsonan oleh masyarakat Batak Toba.

\section{Metode}

Penelitian ini menggunakan beberapa metode yang dipakai sebagai dasar untuk memecahkan analisis geminat (penggandaan) konsonan yang terdapat dalam bahasa Batak Toba. Metode tersebut pada pokoknya dapat dibagi menjadi dua macam yaitu metode subjektif atau intuitif (di mana peneliti turut aktif sebagai informan). Metode subjektif atau intuitif digunakan dalam penelitian geminate (penggandaan) konsonan dengan pendekatan nilai diplomasi (Limbong et al., 2018). Sedangkan metode2 Objektif meliputi metode deskriptif atau penggambaran (Baried 1983:6)

\section{Teknik Pengumpulan Data}

Menurut Sugiyono (2013:224) teknik pengumpulan data merupakan langkah yang paling strategis dalam penelitian, karena tujuan utama dari penelitian adalah mendapatkan data.

1. Teknik Wawancara, Menurut Esterberg dalam Sugiyono (2013:231) wawancara merupakan pertemuan dua orang untuk bertukar informasi dan ide melalui tanya jawab, sehingga dapat dikontruksikan makna dalam suatu topik tertentu.

\section{Teknik Pengamatan/Observasi, Sutrisno} Hadi dalam Sugiyono (2013:145) mengemukakan bahwa, observasi merupakan suatu proses yang kompleks, suatu proses yang tersusun dari berbagai proses biologis dan psikhologis. Dua di antara yang terpenting adalah proses-proses pengamatan dan ingatan.

3. Teknik Dokumentasi, Menurut Sugiyono (2013:240) dokumen merupakan catatan peristiwa yang sudah berlalu. Dokumen bisa berbentuk tulisan, gambar, atau karya-karya monumental dari seorang. Dokumen yang berbentuk tulisan misalnya catatan harian, sejarah kehidupan (life histories), ceritera, biografi, peraturan, kebijakan. Dokumen yang berbentuk gambar misalnya foto, gambar hidup, sketsa dan lain-lain. Dokumen yang berbentuk karya misalnya karya seni, yang dapat berupa gambar, patung, film dan lainlain. Studi dokumen merupakan pelengkap dari penggunaan metode observasi dan wawancara dalam penelitian kualitatif.

4. Triangulasi, dalam teknik pengumpulan data, triangulasi diartikan sebagai teknik pengumpulan data yang bersifat menggabungkan dari berbagai teknik pengumpulan data dan sumber data yang telah ada.

Penelitian ini dilaksanakan di desa Sitorang Jae, Kecamatan Narumonda Kabupaten Toba Samosir. Dengan jumlah responden sebanyak 30 orang. Hasil penelitian diperoleh dengan wawancara kepada informan maupun hasil penelitian para ahli, semua ini merupakan bahan penelitian tradisi lisan Batak Toba.

\section{Kesimpulan}

Hasil penelitian analisis geminate (penggandaan)konsonan dalam bahasa Batak Toba adalah sebagai berikut:

1. Geminat murni (sejati) dalam bentuk kosakata terdiri dari konsonan [bb], [cc], [dd], [jj], [kk], [pp], [ss], [tt]

2. Geminate dalam bahasa Batak Toba dapat terjadi akibat proses afiksasi

3. Afiks yang dapat membentuk geminate dalam bahasa Batak Toba adalah prefiks me + kata dasar yang fonem awalnya adalah [h], [t], $[\mathrm{s}]$, prefiks pe + kata dasar yang fonem awalnya adalah [s].

4. Geminate juga terjadi karena proses morfofonemik

Contoh: MaN + kata dasar yang fonem awalnya bunyi [n]. bunyi nasal [N] akan berubah menjadi b-.ma $\mathrm{N}+$ boan [mabboan] membawa

5. Geminat dalam bahasa Batak Toba terjadi karena proses afiksasi yakni leketnya sufiks 
pada kata dasar. Sufiks hon + kata dasar yang berakhiran bunyi $[\mathrm{k}]$

Contoh : dirgak + hon [dirgakkon] dtegakkan

Sufiks an + kata dasar yang berakhiran bunyi [n]

Contoh : malo + an [maloan] lebih pintar

Sufiks i + kata dasar yang berakhiran bunyi [i]

Contoh : sipak+ I [sipaki], [manipaki], sering menyepak

Sufiks on + kata dasar yang berakhiran bunyi [n]

Contoh : sabi + on [sabion], waktu menyabit.

\section{DaftarPustaka}

Arikunto, Suharsimi. 2006. Prosedur Penelitian Suatu Pendekatan Praktik, Jakarta: Rineka Cipta

$2006 . \quad$ Dasar-Dasar

EvaluasiPendidikan (Edisi Revisi). Jakarta: Bumi Aksara

Depdiknas. 2005. Kamus Besar Bahasa Indonesia. Jakarta: Balai Pustaka

Keraf, Gorys. 1980. Tata Bahasa Indonesia. Ende-Flores: Nusa Indah

Mulyono, Anton dkk. 2000. Tata Bahasa Baku Bahasa Indonesia. Jakarta: Balai Pustaka

Nababan, P.W.J. A Grammar of Batak Toba, Camberra: Pacific Linguistic, 1981(edisi revisi)

Sibarani Robert MS, 1997.'Sintaksis Bahasa Batak Toba.' USU Press, Medan.

Sinaga, Anicetus. 2014. Tata Bahasa Batak Toba. Medan: Bina Media Perintis

Sugiyono, 2013. Metode Penelitian Kuantitatif, Kualitatif dan R\&D. Bandung: Penerbit Alfabeta.
Limbong, T., \& Silitonga, P. D. P. (2016). LOCAL

DEVELOPMENT

APPLICATION OF LEARNING CONTENT-BASED MULTIMEDIA BATAK TOBA SCRIPTS. AISTELL Universitas Negeri Medan, 1(1), 544551. Retrieved from http://aisteel.unimed.ac.id/proceedingaisteel-2016/

Limbong, T., Simarmata, J., Tambunan, A. R. S., Siagian, P., Panjaitan, J., Siagian, L., ... Lumbanbatu, K. (2018). The implementation of computer based instruction model on Gost Algorithm Cryptography Learning. IOP Conference Series: Materials Science and Engineering, 420(1), 12094. IOP Publishing. 